\title{
Oxidation of methionine and 2-hydroxy 4-methylthiobutanoic acid stereoisomers in chicken tissues
}

\author{
BY LILIANE DUPUIS, C. LINDA SAUNDERSON*, ANTOINE PUIGSERVER† \\ AND PATRICK BRACHET \\ Centre de Biochimie et de Biologie Moléculaire du CNRS, BP 71, 13402 Marseille, Cédex 9. \\ France
}

(Received 30 March 1988 - Accepted 8 February 1989)

\begin{abstract}
Oxidation of DL-2-hydroxy 4-methylthiobutanoic acid (DL-HMB), DL-methionine (DL-MET) and Lmethionine (L-MET) in chicken tissue homogenates was compared using $1-^{14} \mathrm{C}$-labelled tracers. The pattern of oxidation of the substrates was similar at both 10 ( $(0.7 \mathrm{mM})$ and high $(20 \mathrm{mM})$ concentrations. The rate of conversion to 2-keto 4-methylthiobutanoic acid (KMB) was highest for DL-MET and lowest for L-MET in kidney, liver and intestinal mucosa. In breast muscle, rates for DL-MET and L-MET were similar at $0.7 \mathrm{mM}$, but DL-HMB showed the highest rate at $20 \mathrm{mM}$. Kidney contained the highest specific activity for oxidation of all three substrates. Raising the $\mathrm{pH}$ of liver and kidney homogenates from 7.5 to 8-6 increased the oxidation of DL-MET, exclusively. Experiments with inhibitors of D-2-hydroxy acid dehydrogenase $(E C$ 1.1.99.6) and L-2-hydroxy acid oxidase $(E C$ 1.1.3.15) suggested that $D-$ and $L-$ HMB were stereospecifically oxidized by the enzymes. KMB stimulated L-MET oxidation in kidney yet inhibited L-MET oxidation in liver homogenates. The effect of KMB on DL-MET and DL-HMB oxidation also varied between tissues. Amino-oxyacetate inhibited L-MET oxidation completely and DLMET and DL-HMB oxidation almost completely in both kidney and liver. L-Cycloserine was less potent than amino-oxyacetate and decreased L-MET oxidation more in kidney than in liver. It can be calculated from the results that, at low substrate concentrations, the liver contributes principally to the whole body oxidation of both DL-HMB and DL-MET. At high (greater than physiological) concentrations, DL-HMB would be oxidized principally in skeletal muscle. At all concentrations, L-MET would be converted to KMB mainly in the muscle.
\end{abstract}

2-Hydroxy 4-methylthiobutanoic acid: Methionine oxidation: Chicken.

Although there are many conflicting reports on the efficiency of supplemental DL-2hydroxy 4-methylthiobutanoic acid (DL-HMB), the methionine hydroxy analogue, compared with DL-methionine (DL-MET) in methionine-deficient practical poultry rations, DL-HMB has repeatedly been shown to have a lower biological efficiency when included in purified diets containing crystalline amino acids (e.g. Featherston \& Horn, 1974; Muramatsu et al. 1984).

The uptake of DL-MET by chicken or rat small intestine was found to be faster (Lerner et al. 1969; Brachet et al. 1986; Brachet \& Puigserver, 1987) than that of DL-HMB. Furthermore, Saunderson $(1985,1987)$ observed a greater excretion from chickens of DLHMB compared with that of DL-MET and L-methionine (L-MET). In chickens (Gordon \& Sizer, 1965) and in rats (Langer, 1965), DL-HMB has been shown to be converted to LMET, essentially in the liver and the kidney (Fig. 1). Transformation of D-2-hydroxy 4methylthiobutanoic acid (D-HMB) and L-2-hydroxy 4-methylthiobutanoic acid (L-HMB) as well as that of D-methionine (D-MET) to L-MET involves stereospecific oxidation to the $\alpha$-keto acid, 2-keto 4-methylthiobutanoic acid (KMB).

* Present address: AFRC Institute for Grassland and Animal Production, Poultry Department, Roslin, Midlothian EH25 9PS.

$\dagger$ For reprints. 


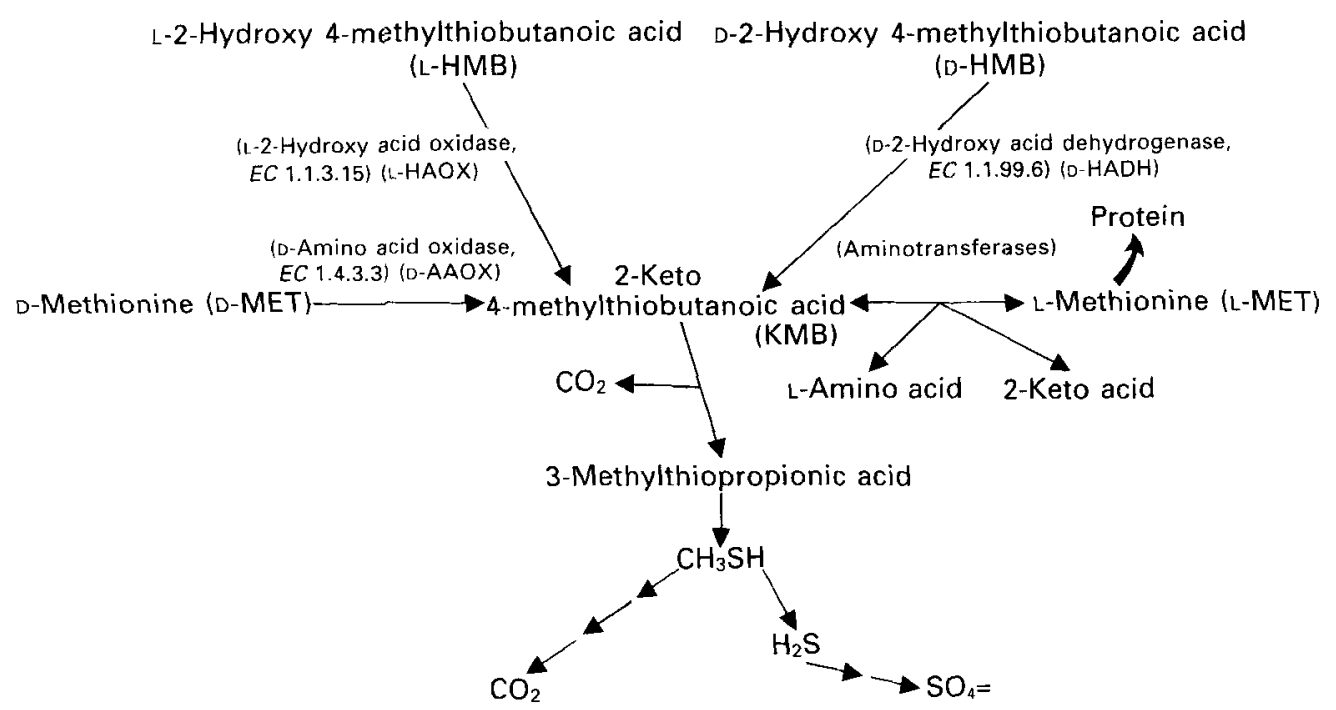

Fig. 1. Metabolism of the stereoisomers of methionine and methionine hydroxy analogue.

Utilization of DL-HMB and DL-MET as substrates for liver protein synthesis in chickens was found to be equivalent in vitro, using primary cultures of chicken hepatocytes (Dibner, 1983), and in vivo, following intraperitoneal injection of ${ }^{14} \mathrm{C}$-labelled methionine sources into the birds (Saunderson, 1985). However, radioactivity was recovered differently from DL- $\left[1-{ }^{14} \mathrm{C}\right] \mathrm{MET}, \mathrm{L}-\left[1-{ }^{14} \mathrm{C}\right] \mathrm{MET}$ and $\mathrm{DL}-\left[1-{ }^{14} \mathrm{C}\right] \mathrm{HMB}$ in proteins of peripheral tissues. Additionally, DL-HMB appeared to be more efficiently converted to L-MET in liver than in kidney, in spite of the wide tissue distribution of D-2-hydroxy acid dehydrogenase ( $E C$ 1.1.99.6; D-HADH) and L-2-hydroxy acid oxidase (EC 1.1.3.15; L-HAOX) in the chicken (Dibner \& Knight, 1984). The studies reported here were designed to assess the tissue oxidation of D- and L-HMB as well as that of D- and L-MET to KMB in an attempt to understand the differing efficiencies of DL-HMB and DL-MET as a methionine source for poultry.

\section{EXPERIMENTAL}

\section{Materials}

$\mathrm{L}-\left[1-{ }^{14} \mathrm{C}\right] \mathrm{MET}(51.5 \mathrm{mCi} / \mathrm{mmol})$ and $\mathrm{DL}-\left[1-{ }^{14} \mathrm{C}\right] \mathrm{HMB}$, calcium or potassium salt $(46 \cdot 3$ $\mathrm{mCi} / \mathrm{mmol}$ ), were respectively provided and synthesized at our request by the Commissariat à l'Energie Atomique, France. Their radiochemical purity was $97-99 \%$ whereas that of DL$\left[1-{ }^{14} \mathrm{C}\right] \mathrm{MET}$, purchased from Amersham International plc, Amersham, Bucks, was 61 (SD $1 \cdot 0) \%$ (two batches). The latter material was further purified by high-performance liquid chromatography (HPLC) using a Waters Associates system consisting of two M 510 pumps, an M 720 solvent programmer, a WISP 710 B multisampler, an M 441 fixedwavelength detector $(214 \mathrm{~nm})$ and an $M 730$ two-channel chart recorder. DL- $\left[1-{ }^{14} \mathrm{C}\right] \mathrm{MET}$ (retention time $6.8 \mathrm{~min}$ ) and its oxidized derivatives (retention time $2.3 \mathrm{~min}$ ) were separated on a Merck Lichrosorb C 18 reversed-phase column $(7 \mu \mathrm{m}, 4 \times 250 \mathrm{~mm})$ by a linear gradient from $100 \%$ trifluoroacetic acid (TFA) to $90 \%$ TFA-10\% acetonitrile within 20 min at a constant flow-rate of $1 \mathrm{ml} / \mathrm{min}$ and at room temperature. The yield in pure DL$\left[1{ }^{14} \mathrm{C}\right] \mathrm{MET}(47.5(\mathrm{SD} 0.9) \mathrm{mCi} / \mathrm{mmol})$ was 38.0 (SD 5.7) \%. HPLC grade acetonitrile and TFA were from SDS, Peypin, France and Sigma Co., St Louis, MO, USA respectively. All other chemicals were of reagent grade and were used without further purification. 
Table 1. Composition of experimental diet* $(\mathrm{g} / \mathrm{kg}$ dry diet $)$

\begin{tabular}{|c|}
\hline Maize \\
\hline Soya-bean meal (500 g protein $/ \mathrm{kg}$ ) \\
\hline Fish-meal $(700 \mathrm{~g}$ protein $/ \mathrm{kg})$ \\
\hline Tallow \\
\hline Furoxone (300 mg active ingredient/g) \\
\hline Mineral and vitamin mixture $\dagger$ \\
\hline DL-Methionine \\
\hline
\end{tabular}

* Crude protein (g/ $\mathrm{kg}$ diet): 229. Amino acid content $(\mathrm{g} / \mathrm{kg}$ diet): lysine $12 \cdot 6$, methionine $3 \cdot 7$, methionine + cysteine $7 \cdot 4$, threonine $8 \cdot 8$, tryptophan $2 \cdot 9$, arginine $14 \cdot 9$, glycine $9 \cdot 5$, glycine + serine $20 \cdot 9$, histidine $5 \cdot 8$, isoleucine $10 \cdot 7$, leucine $20 \cdot 2$, phenylalanine $11 \cdot 5$, phenylalanine + tyrosine $19 \cdot 7$, valine $11 \cdot 7$.

$\dagger$ Contained minerals and vitamins $(\mathrm{g} / \mathrm{kg}$ diet) as follows: dicalcium phosphate 17.5 , calcium carbonate 10.74 , salt mixture 4 , vitamins (A, B, D, E) $0 \cdot 25$, choline (500 g choline $/ 1) 1 \cdot 99$, trace elements $0 \cdot 5$.

\section{Animals}

Broiler chickens (1-d-old; Arbor Acres strain) were obtained from Ets Albert, Crest, France. All birds were reared under natural lighting conditions in a room with controlled temperature and ventilation. They were allowed free access to food (standard chick starter ration, Table 1) and to water until used for the experiment at $28-31 \mathrm{~d}$ of age.

\section{Tissue collection}

Chickens (1082 (SD 204) g, $n$ 90) were killed by decapitation and their liver, kidney, small intestine and breast muscle were rapidly excised. After perfusing the liver through the portal vein and rinsing the small intestine with ice-cold saline ( $9 \mathrm{~g}$ sodium chloride/1), all the tissues were weighed, quickly frozen in liquid nitrogen and then stored at $-80^{\circ}$ until use.

\section{Tissue preparation and incubation}

Except for the small intestinal mucosa which was initially scraped off with a microscope slide, the thawing tissues were rapidly homogenized with a Potter-Elvehjem glass-teflon or a Polytron (for breast muscle) homogenizer in 4 vol. $20 \mathrm{~mm}$-potassium phosphate or TrisHepes buffer, pH 7.5, containing $0.25 \mathrm{M}$-sucrose, $1 \mathrm{~mm}$-benzamidine and $1 \mathrm{~mm}$-dithiothreitol. In some experiments the homogenates were pre-incubated with $0.8 \mathrm{~mm}$-aminooxyacetate, L-cycloserine or without inhibitor (control), and gassed with oxygen carbon dioxide $\left(95: 5, \mathrm{v} / \mathrm{v}\right.$ ) for $15 \mathrm{~min}$ at $4^{\circ}$ (Table 6). Routinely, the homogenates were incubated at $37^{\circ}$ with continuous agitation $(120 \mathrm{rev} / \mathrm{min})$ in $100-\mathrm{ml}$ rubber-stoppered Erlenmeyer flasks (Benevenga et al. 1983) containing $3.6 \mathrm{mM}$-magnesium chloride, $1 \mathrm{~mm}$ benzamidine, $1 \mathrm{~mm}$-dithiothreitol, and $0.3 \mu \mathrm{Ci}(0.7 \mathrm{mM}){ }^{14} \mathrm{C}$-labelled substrate (L-MET, DLMET or DL-HMB) dissolved in the appropriate buffer. In some cases, the reaction mixture also contained 0.34 mM-FAD (sodium salt) or FMN (sodium salt), or both, or was buffered at pH 8.6 (Table 4, see p. 69). Other experiments were carried out in the presence of one (Table 5, see p. 69) or two (Table 6, see p. 70) of the following effectors (10 mM): L-HMB (calcium salt) (L-HMB Ca ${ }^{2+}$ ), D-HMB (potassium salt), glycolate (potassium salt), $\beta$ phenyl-L-lactate (potassium salt), D-lactate (lithium salt), L-lactate (lithium salt), D-malate (potassium salt), D-MET, L-MET, L-leucine and L-phenylalanine. The effect of $10 \mathrm{~mm}$ $\mathrm{KMB}$ on the reaction was measured in the presence of $1.6 \mu \mathrm{Ci}(5 \mathrm{~mm}){ }^{14} \mathrm{C}$-labelled substrate (Table 7 , see p. 71$)$ while $2 \mu \mathrm{Ci}(20 \mathrm{~mm})$ material were added in studies at saturating substrate concentration (Tables 2 and 3, see pp. 67 and 68).

After saturating the incubation buffer $(2.5 \mathrm{ml})$ with pure $\mathrm{O}_{2}$, reactions were initiated on 
addition of the homogenate $(1 \mathrm{ml})$ and stopped with $2.5 \mathrm{ml} 5^{\prime}$-sulphosalicyclic acid $(116-2$ g/l) (Graser et al. 1985). Controls were obtained by simultaneously injecting the homogenate and the acid into the incubation buffer and processing as previously described.

\section{Sample analysis}

After the reaction was stopped, the accumulated $\left[1-{ }^{14} \mathrm{C}\right] \mathrm{KMB}$ was assayed as the ${ }^{14} \mathrm{CO}_{2}$ evolved on addition of $6 \mathrm{ml}$ hydrogen peroxide $(300 \mathrm{ml} / \mathrm{l})$ (Odessey $\&$ Goldberg, 1979). The flasks were shaken for a further $2 \mathrm{~h}$ in order to ensure complete recovery of the released $\mathrm{CO}_{2}$ in $0.75 \mathrm{ml} \beta$-phenylethylamine (Hauschildt \& Brand, 1980) contained in a well in the centre of the flask. The contents of the central well were added to $7.5 \mathrm{ml}$ scintillation fluid (Phase Combining System, Amersham) and the radioactivity determined in a Beckman LS 3800 liquid-scintillation counter. Values were corrected for the corresponding control value and expressed as nmol $\mathrm{KMB}$ accumulated $/ \mathrm{mg}$ protein or $\mathrm{g}$ tissue, thus taking into account the specific radioactivity of the substrate. This method of estimation of $\left[{ }^{14} \mathrm{C}\right] \mathrm{KMB}$ also included any $\left[{ }^{14} \mathrm{C}\right] \mathrm{KMB}$ that was decarboxylated by dehydrogenase enzymes in the tissue homogenates (Jones \& Yeaman, 1986). The protein content of the tissue homogenates was determined by the method of Hartree (1972) using bovine serum albumin as the standard. Initial rates ( $\mathrm{nmol} / \mathrm{min}$ per $\mathrm{mg}$ protein) were derived from the linear portion of the curves for product formed $v$. time.

\section{Statistical analysis}

Results were expressed as means with their standard deviations. Statistical significance was assessed using the Student's $t$ test in order to compare the 'raw' rates of $\left[{ }^{14} \mathrm{C}\right] \mathrm{KMB}$ accumulation from all substrates or, alternatively, in all tissues. The differences were judged to be significant at $P<0.05$. For estimation of initial reaction rates linear regression analyses of product formation with time for incubations of less than $10 \mathrm{~min}$ were used. These were used to compare correlation coefficients, slopes with standard deviations, and intercepts. Although variances of product formation were related to means, it is reasonable to use untransformed data in this procedure provided ranges are not too large (Cleland, 1979).

\section{RESULTS}

The concentrations of free endogenous methionine in various tissue homogenates were measured and found never to exceed $5 \%$ of the exogenous methionine concentration in the incubation mixtures $(0.7 \mathrm{~mm})$. Since endogenous methionine did not modify the specific radioactivity of the added $L-\left[1-{ }^{14} \mathrm{C}\right]-$ or $\mathrm{DL}-\left[1{ }^{14} \mathrm{C}\right] \mathrm{MET}$, no corrections were made to the values. No loss of activity of $\left[{ }^{14} \mathrm{C}\right] \mathrm{KMB}$ accumulation from the three substrates was observed with the frozen tissues compared with the corresponding fresh materials. In addition the initial $\mathrm{pH}$ of the media $(7 \cdot 5)$ did not change on prolonged incubation $(1 \mathrm{~h})$.

\section{Time-course of KMB formation in homogenates}

The time-course of $\left[{ }^{14} \mathrm{C}\right] \mathrm{KMB}$ formation from DL- $\left[1-{ }^{14} \mathrm{C}\right] \mathrm{MET}, \mathrm{L}-\left[1-{ }^{14} \mathrm{C}\right] \mathrm{MET}$ and DL- $[1-$ $\left.{ }^{14} \mathrm{C}\right] \mathrm{HMB}(20 \mathrm{mM})$ in homogenates of several chicken tissues is shown in Fig. 2. Tissue oxidation of these substrates at low $(0.7 \mathrm{mM})$ concentration showed very similar patterns to those in Fig. 2, but the reaction rates generally decreased after 5-10 min due to depletion of substrate. DL-MET was the best KMB-producing substrate in all the tissues examined with the exception of muscle where activities were similar to L-MET at $0.7 \mathrm{~mm}$ (values not shown) and lower than DL-HMB up to the first $5 \mathrm{~min}$ period of incubation at $20 \mathrm{mM}$. The initial rates of KMB formation from L-MET, DL-MET and DL-HMB in the different tissue 


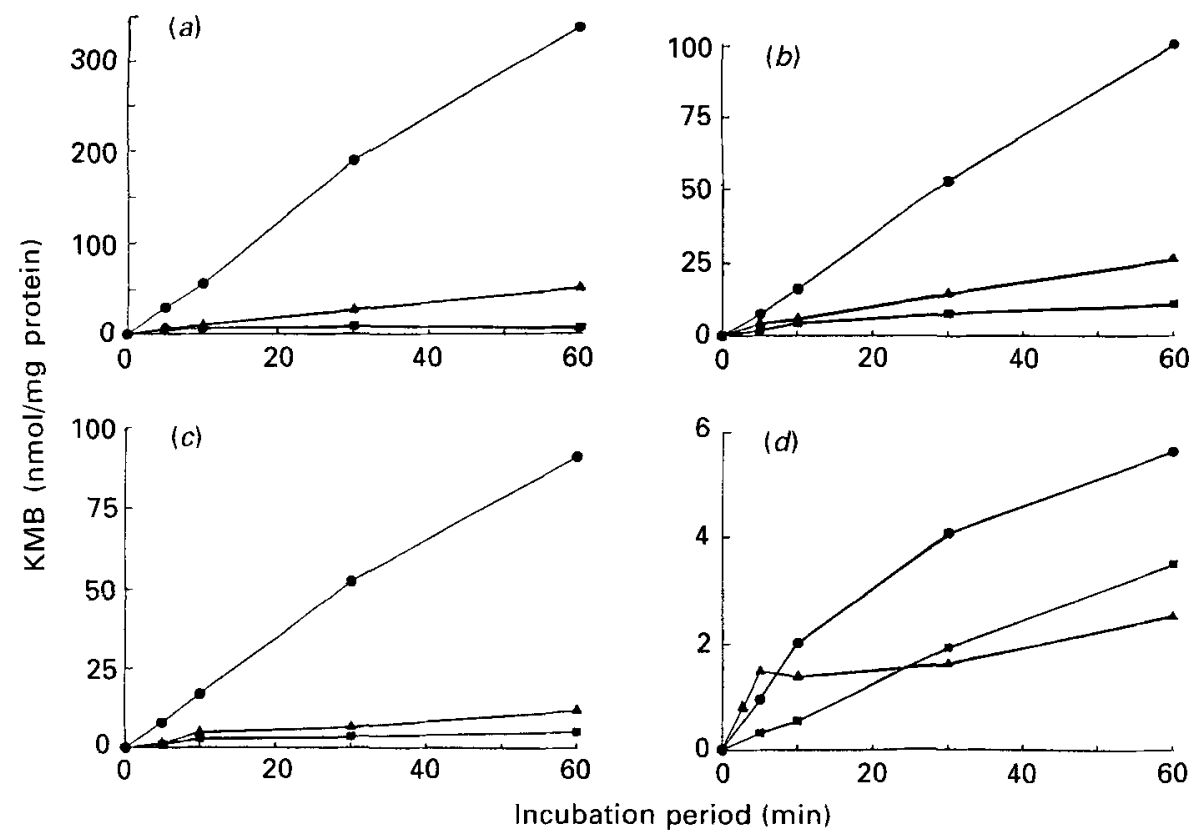

Fig. 2. Time-course of 2-keto 4-methylthiobutanoic acid (KMB) accumulation from $20 \mathrm{mM}$-DL- $\left[1-{ }^{14} \mathrm{C}\right] \mathrm{methionine}$ (O), DL- $\left[1-{ }^{14} \mathrm{C}\right] 2$-hydroxy 4-methylthiobutanoic acid (A) and $\mathrm{L}-\left[1-{ }^{14} \mathrm{C}\right]$ methionine ( $\left.\boldsymbol{(}\right)$ in chicken tissue homogenates: $(a)$ kidney, $(b)$ liver, $(c)$ intestinal mucosa and $(d)$ breast muscle. The values are the mean values for at least four determinations. The standard deviations were $<20 \%$ of the mean.

Table 2. The specific activities of chicken tissue homogenates for 2-keto 4-methylthiobutanoic acid $(K M B)$ formation from the three substrates

(Results are expressed as initial rates ( $\mathrm{nmol} / \mathrm{min}$ ) of KMB accumulation per $\mathrm{mg}$ protein. Mean values and standard deviations for at least four determinations (two experiments with two different animals))

\begin{tabular}{|c|c|c|c|c|c|c|c|}
\hline \multirow{2}{*}{$\begin{array}{l}\text { Substrate... } \\
\text { Tissue }\end{array}$} & & \multicolumn{2}{|c|}{ L-MET } & \multicolumn{2}{|c|}{ DL-MET } & \multicolumn{2}{|c|}{ DL-HMB } \\
\hline & & $0.7 \mathrm{mM}$ & $20 \mathrm{~mm}$ & $0.7 \mathrm{~mm}$ & $20 \mathrm{~mm}$ & $0.7 \mathrm{~mm}$ & $20 \mathrm{~mm}$ \\
\hline Liver & $\begin{array}{l}\text { Mean } \\
\text { SD }\end{array}$ & $\begin{array}{l}0.091^{\mathrm{a}} \\
0-013\end{array}$ & $\begin{array}{l}0.406^{\mathrm{d}} \\
0.051\end{array}$ & $\begin{array}{l}0.634^{b} \\
0.139\end{array}$ & $\begin{array}{l}1.659^{\mathrm{e}} \\
0.191\end{array}$ & $\begin{array}{l}0 \cdot 228^{e} \\
0-060\end{array}$ & $\begin{array}{l}0.532^{\mathrm{f}} \\
0.089\end{array}$ \\
\hline Kidney & $\begin{array}{l}\text { Mean } \\
\text { SD }\end{array}$ & $\begin{array}{l}0.199^{\mathrm{a}} \\
0.022\end{array}$ & $\begin{array}{l}0 \cdot 810^{\mathrm{d}} \\
0 \cdot 107\end{array}$ & $\begin{array}{l}2 \cdot 057^{\mathrm{h}} \\
0.364\end{array}$ & $\begin{array}{l}5.803^{e} \\
0.824\end{array}$ & $\begin{array}{l}0 \cdot 391^{\circ} \\
0 \cdot 107\end{array}$ & $\begin{array}{l}1.001^{\mathrm{d}} \\
0.199\end{array}$ \\
\hline Breast muscle & $\begin{array}{l}\text { Mean } \\
\text { SD }\end{array}$ & $\begin{array}{l}0.039^{\mathrm{a}} \\
0.008\end{array}$ & $\begin{array}{l}0.091^{\mathrm{d}} \\
0.022\end{array}$ & $\begin{array}{l}0.044^{\mathrm{a}} \\
0.015\end{array}$ & $\begin{array}{l}0.198^{\mathrm{e}} \\
0.018\end{array}$ & $\begin{array}{l}0.005^{\mathrm{c}} \\
0.002\end{array}$ & $\begin{array}{l}0.376^{\mathrm{f}} \\
0.069\end{array}$ \\
\hline Intestinal mucosa & $\begin{array}{l}\text { Mean } \\
\text { SD }\end{array}$ & $\begin{array}{l}0.019^{\mathrm{a}} \\
0.005\end{array}$ & $\begin{array}{l}0.241^{\mathrm{d}} \\
0.069\end{array}$ & $\begin{array}{l}0.397^{\mathrm{b}} \\
0.068\end{array}$ & $\begin{array}{l}1.648^{\mathrm{e}} \\
0.322\end{array}$ & $\begin{array}{l}0.049^{\mathrm{c}} \\
0.008\end{array}$ & $\begin{array}{l}0.385^{d} \\
0.204\end{array}$ \\
\hline
\end{tabular}

L-MET, L-methionine; DL-MET, DL-methionine; DL-HMB, DL-2-hydroxy 4-methylthiobutanoic acid.

a-f Within rows, and at a given concentration, treatment means with different superscript letters differed significantly $(P<0.05)$.

homogenates were measured during the period over which the time-course was linear. The values obtained at the two substrate concentrations used are given in Table 2 . The specific activities for DL-MET, L-MET and DL-HMB oxidation in the kidney were found to be about $3.3,2 \cdot 1$ and 1.7 times that in the liver respectively, whatever the concentration considered. The kidney was again severalfold more active than the two other tissues, but the differences 
Table 3. The ability of chicken tissue homogenates to produce 2-keto 4-methylthiobutanoic acid $(K M B)$ from the three substrates

(The total tissue capacity $(\mu \mathrm{mol} / \mathrm{h}$ ) was derived from the specific activity of the corresponding homogenate (values in Table 2 expressed per $\mathrm{g}$ wet tissue) and the organ weight of 4-week-old chicks. Means values and standard deviations for at least two experiments)

\begin{tabular}{|c|c|c|c|c|c|c|c|c|}
\hline \multirow[b]{2}{*}{ Tissue } & & \multirow{2}{*}{$\begin{array}{c}\text { Wet wt } \\
\text { (g/kg total } \\
\text { body-w1) }\end{array}$} & \multicolumn{2}{|c|}{ L-MET } & \multicolumn{2}{|c|}{ DL-MET } & \multicolumn{2}{|c|}{ DL-HMB } \\
\hline & & & $0.7 \mathrm{mM}$ & $20 \mathrm{~mm}$ & $0.7 \mathrm{~mm}$ & $20 \mathrm{~mm}$ & $0.7 \mathrm{mM}$ & $20 \mathrm{~mm}$ \\
\hline Liver & $\begin{array}{l}\text { Mean } \\
\text { SD }\end{array}$ & $\begin{array}{r}28.8 \\
3.7\end{array}$ & $\begin{array}{r}22.44 \\
6.08\end{array}$ & $\begin{array}{r}100 \cdot 12 \\
25 \cdot 44\end{array}$ & $\begin{array}{r}156 \cdot 34 \\
54 \cdot 36\end{array}$ & $\begin{array}{r}409.13 \\
99.66\end{array}$ & $\begin{array}{l}56 \cdot 22 \\
22 \cdot 01\end{array}$ & $\begin{array}{r}131 \cdot 19 \\
38 \cdot 80\end{array}$ \\
\hline Kidney & $\begin{array}{l}\text { Mean } \\
\text { so }\end{array}$ & $\begin{array}{l}8 \cdot 5 \\
1 \cdot 1\end{array}$ & $\begin{array}{r}10.59 \\
2.54\end{array}$ & $\begin{array}{l}43 \cdot 11 \\
11 \cdot 27\end{array}$ & $\begin{array}{r}109.48 \\
33.54\end{array}$ & $\begin{array}{r}308.86 \\
83.83\end{array}$ & $\begin{array}{r}20 \cdot 81 \\
8 \cdot 39\end{array}$ & $\begin{array}{l}53 \cdot 27 \\
17 \cdot 48\end{array}$ \\
\hline Muscle & $\begin{array}{l}\text { Mean } \\
\text { SD }\end{array}$ & $\begin{array}{r}286.9 \\
16.3\end{array}$ & $\begin{array}{l}70 \cdot 15 \\
18 \cdot 37\end{array}$ & $\begin{array}{r}163.69 \\
48.87\end{array}$ & $\begin{array}{l}79 \cdot 15 \\
31 \cdot 48\end{array}$ & $\begin{array}{r}356.17 \\
52.61\end{array}$ & $\begin{array}{l}8.99 \\
4.11\end{array}$ & $\begin{array}{l}676.37 \\
162.66\end{array}$ \\
\hline $\begin{array}{c}\text { Intestinal } \\
\text { mucosa }\end{array}$ & $\begin{array}{l}\text { Mean } \\
\text { SD }\end{array}$ & $\begin{array}{l}5 \cdot 3 \\
1 \cdot 1\end{array}$ & $\begin{array}{l}0 \cdot 84 \\
0 \cdot 39\end{array}$ & $\begin{array}{r}10.61 \\
5.24\end{array}$ & $\begin{array}{r}17.49 \\
6.67\end{array}$ & $\begin{array}{l}72 \cdot 60 \\
29 \cdot 25\end{array}$ & $\begin{array}{l}2 \cdot 16 \\
0 \cdot 80\end{array}$ & $\begin{array}{l}16.96 \\
12.51\end{array}$ \\
\hline
\end{tabular}

L-MET, L-methionine; DL-MET, DL-methionine; DL-HMB, DL-2 hydroxy 4-methylthiobutanoic acid.

observed were generally the highest when the substrate was present at $0.7 \mathrm{~mm}$. It is interesting that, unlike L-MET and DL-HMB, DL-MET was readily oxidized to KMB in homogenates of intestinal mucosa.

The overall ability of the tissues to convert the three substrates to KMB was estimated from the values in Table 2 and the tissue weights. Assuming that breast muscle is a representative sample of the whole tissue, Table 3 shows that at the concentration $0.7 \mathrm{~mm}$ both the DL-MET and DL-HMB oxidation capacities of the liver would be greater than those of the other tissues. The same conclusion was reached with $20 \mathrm{~mm}$-DL-MET; however, the relative contribution of the muscle would be markedly increased. Changing the concentration from 0.7 to $20 \mathrm{~mm}$ could alter the tissue distribution of DL-HMB oxidation which would become the highest in muscle. The oxidation pattern of L-MET would differ from that of both DL-MET and DL-HMB: at the low and at the high concentration, the muscle could have by far the highest capacity. However, evaluation of the overall enzymic activity of muscles would be useful to ascertain the complete validity of the abovementioned assumption.

\section{Effects of optimum $p H$ and cofactors of oxidases on MET and HMB oxidation}

Studies with purified L-HAOX (Nakano et al. 1968; Cromartie \& Walsh, 1975), D-HADH (Tubbs \& Greville, 1961) and D-amino acid oxidase (EC 1.4.3.3, D-AAOX; Dixon \& Kleppe, $1965 b$ ) have shown maximal enzyme activity at about $\mathrm{pH} 8.5$. As shown in Table 4 , the oxidation of DL-MET by homogenates of chicken liver and kidney was enhanced 1.3and 1.4-fold when the $\mathrm{pH}$ of the medium was increased from $7 \cdot 5$ to $8 \cdot 6$. The oxidation of DL-HMB was not significantly altered by changing the $\mathrm{pH}$. Since the enzymes D-AAOX and D-HADH are flavoenzymes with the prosthetic group of FAD, and L-HAOX contains the prosthetic group of FMN (Cammack, 1969; Masters \& Holmes, 1977), incubations were carried out in the presence of FAD or FMN, or both. These cofactors were added at a concentration of $340 \mu \mathrm{M}$ since this was shown fully to restore the activity of conversion of DL-HMB to L-MET in preparations of rat liver depleted in small-molecular-weight solutes (Langer, 1965). With chicken liver and kidney homogenates, however, neither the oxidation of DL-HMB nor that of DL-MET was changed significantly by adding the flavin cofactors (Table 4). 
Table 4. Effects of optimum $p H$ and cofactors of oxidases on the conversion of $D L$ methionine (DL-MET) and DL-2 hydroxy 4-methylthiobutanoic acid (DL-HMB) to 2-keto 4-methylthiobutanoic acid $(K M B)$

(Tissues were homogenized in the phosphate buffer at $\mathrm{pH} 7.5$ or 8.6 . Incubations were carried out, either at $\mathrm{pH} 7.5$ without (control) or with $340 \mu \mathrm{M}-\mathrm{FAD}$ or FMN, or both, or at $\mathrm{pH} 8.6$. Initial rates of $\mathrm{KMB}$ production from the substrates $(0.7 \mathrm{mM})$ were determined as indicated (see p. 66$)$. Values ( $\%$ of control activity) are the mean values and standard deviations of five or six observations)

\begin{tabular}{|c|c|c|c|c|c|}
\hline \multirow[b]{2}{*}{ Substrate } & \multirow[b]{2}{*}{ Conditions } & \multicolumn{2}{|c|}{ Liver } & \multicolumn{2}{|c|}{ Kidney } \\
\hline & & Mean & SD & Mean & $S D$ \\
\hline DL-MET & $\begin{array}{l}\text { pH } 8.6 \\
+ \text { FAD }\end{array}$ & $\begin{array}{l}132^{*} \\
114\end{array}$ & $\begin{array}{r}17 \\
9\end{array}$ & $\begin{array}{l}139^{*} \\
105\end{array}$ & $\begin{array}{l}7 \\
8\end{array}$ \\
\hline DL-HMB & $\begin{array}{c}\text { pH } 8.6 \\
+ \text { FAD and } \\
\text { FMN }\end{array}$ & $\begin{array}{r}90 \\
110\end{array}$ & $\begin{array}{r}7 \\
15\end{array}$ & $\begin{array}{r}106 \\
92\end{array}$ & $\begin{array}{r}18 \\
3\end{array}$ \\
\hline
\end{tabular}

* Mean values were significantly different from the control value $(P<0.05)$.

Table 5. Effects of substrates and inhibitors of D-2-hydroxy acid dehydrogenase (EC 1.1.99.6; D-HADH), L-2-hydroxy acid oxidase (EC 1.1.3.15; L-HAOX) and D-amino acid oxidase (EC 1.4.3.3; $D$-AAOX) on oxidation of $D L$-methionine (DL-MET), DL-2hydroxy 4-methylthiobutanoic acid $(D L-H M B)$ and L-methionine (L-MET) in chicken liver homogenates

(Tissues were homogenized in $20 \mathrm{~mm}$-phosphate or, exceptionally, in Tris-Hepes buffer (pH 7.5) when the reaction mixture included L-2-hydroxy 4-methylthiobutanoic acid (L-HMB calcium salt) and the incubations were processed as described previously (see p. 65) without (control) or with $10 \mathrm{mM}$ of the effectors listed. Values (\% control activity) are the mean values and standard deviations of two to eight experiments)

\begin{tabular}{|c|c|c|c|c|c|c|}
\hline \multirow{2}{*}{$\begin{array}{l}\text { Substrate... } \\
\text { Additions }\end{array}$} & \multicolumn{2}{|c|}{ DL-HMB } & \multicolumn{2}{|c|}{ DL-MET } & \multicolumn{2}{|c|}{ L-MET } \\
\hline & Mean & SD & Mean & SD & Mean & SD \\
\hline None (phosphate buffer) & 100 & - & 100 & - & 100 & - \\
\hline None (Tris-Hepes $+5 \mathrm{mM}^{-\mathrm{Ca}^{2+}}$ ) & $121^{*}$ & 10 & $77^{*}$ & 1 & 100 & 7 \\
\hline D-HMB & $43^{*}$ & 13 & $17^{*}$ & 5 & $68^{*}$ & 5 \\
\hline D-Lactate & $56^{*}$ & 9 & $60^{*}$ & 1 & $68^{*}$ & 6 \\
\hline D-Malate & - & - & 97 & 4 & 89 & 1 \\
\hline $\mathrm{L}-\mathrm{HMB} \mathrm{Ca}{ }^{2+} \uparrow$ & $35^{*}$ & 9 & $12^{*}$ & 1 & $80^{*}$ & 11 \\
\hline$\beta$-Phenyl L-lactate & $51^{*}$ & 10 & $19^{*}$ & 1 & $31^{*}$ & 6 \\
\hline Glycolate & $73^{*}$ & 12 & $59^{*}$ & 7 & 100 & 24 \\
\hline L-Lactate & 103 & 24 & - & - & - & - \\
\hline D-MET & 105 & 15 & - & - & $156^{*}$ & 33 \\
\hline L-MET & $60^{*}$ & 5 & $47^{*}$ & 1 & - & - \\
\hline L-Leucine & 117 & 26 & - & - & - & - \\
\hline L-Phenylalanine & 90 & 14 & - & - & - & - \\
\hline
\end{tabular}

* Mean values were significantly different from control values $(P<0.05)$.

$\dagger$ Compared with Tris-Hepes buffer $+5 \mathrm{mM}^{-\mathrm{Ca}^{2+}}$ conditions.

\section{Effects of substrates and inhibitors of oxidases on MET and HMB oxidation in chicken} liver homogenates

The results obtained on the effect of inhibitors $(10 \mathrm{~mm})$ of hydroxy acid and amino acid oxidases on the oxidation of DL-HMB and DL-MET $(0.7 \mathrm{mM})$ by chicken liver homogenates 
Table 6. Effects of substrates and inhibitors of D-2-hydroxy acid dehydrogenase (EC $1.1 .99 .6 ; D-H A D H), L-2-h y d r o x y$ acid oxidase (EC 1.1.3.15; L-HAOX) and D-amino acid oxidase (EC 1.4.3.3; D-AAOX) on oxidation of DL-2-hydroxy 4-methylthiobutanoic acid $(D L-H M B)$

(The experiments were carried out as described in Table 5 and in the Experimental section. The concentration of any effector used was $10 \mathrm{~mm}$. Values ( $\%$ of control activity) are the mean values and the standard deviations of two to six experiments)

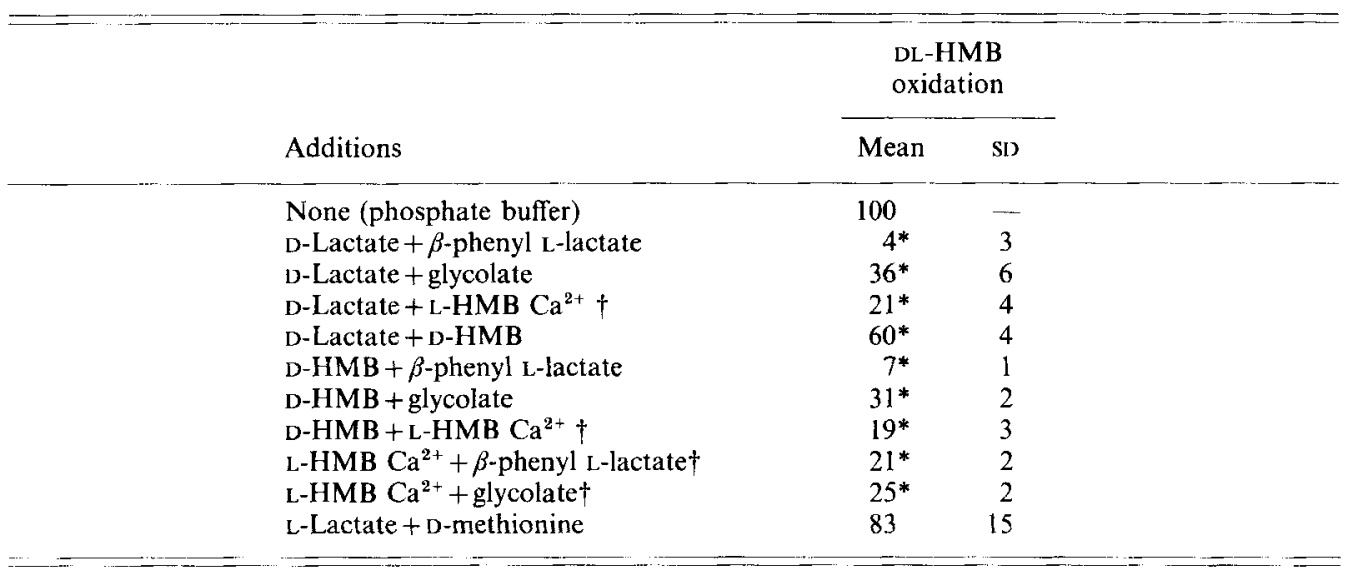

* Mean values were significantly different from the control values $(P<0-05)$.

+ Compared with Tris-Hepes buffer $+5 \mathrm{~mm}^{-\mathrm{Ca}^{2+}}$ conditions.

are summarized in Tables 5 and 6. D-Lactate, a good substrate for D-HADH occurring in tissues of various animals (Tubbs \& Greville, 1961; Cammack, 1969), inhibited the oxidation of DL-HMB by $44 \%$. Glycolate, a good substrate for pig kidney and rat liver LHAOX-A (Robinson et al. 1962; Nakano et al. 1968) inhibited DL-HMB oxidation by $27 \%$ while $\beta$-phenyl L-lactate, a good substrate for pig kidney L-2-hydroxy acid oxidase ( $L$ HAOX-B; Robinson et al. 1962) and rat kidney L-amino acid oxidase (L-AAOX; Nakano \& Danowski, 1966) decreased oxidation by $49 \%$. D-HMB and L-HMB Ca ${ }^{2+}(10 \mathrm{~mm})$ also inhibited DL-HMB oxidation markedly. L-MET inhibited DL-HMB oxidation to a significant degree but D-MET, L-leucine, L-phenylalanine and L-lactate caused no change in oxidation. The effects of two inhibitors together on DL-HMB oxidation are shown in Table 6. Adding $\beta$-phenyl L-lactate with D-lactate or D-HMB almost completely abolished DL-HMB oxidation. The combination of glycolate plus D-lactate or D-HMB was less inhibitory (than $\beta$-phenyl L-lactate plus D-lactate), while L-HMB $\mathrm{Ca}^{2+}$ with D-HMB, Dlactate, glycolate or $\beta$-phenyl L-lactate produced inhibitions between those of the other two groups. By contrast, the inhibitory effect was not significantly changed when D-lactate and D-HMB were either simultaneously or separately added to the incubation medium. As could be predicted from the lack of effect with either alone, L-lactate and D-MET together showed no inhibition of DL-HMB oxidation.

All inhibitors of DL-HMB oxidation also inhibited DL-MET oxidation (Table 5), although D-HMB, L-HMB Ca ${ }^{2+}$, and $\beta$-phenyl L-lactate had greater effects on DL-MET than on DL-HMB oxidation. The effect of inhibitors of DL-HMB oxidation on L-MET oxidation is also shown in Table 5. D-HMB, D-lactate and L-HMB Ca ${ }^{2+}$ all inhibited to a minor degree, while $\beta$-phenyl L-lactate was an effective inhibitor. Glycolate and D-malate had no effect on L-MET oxidation, while D-MET increased the oxidation 1-5-fold. 


$$
\text { TISSUE OXIDATION OF METHIONINE AND HMB }
$$

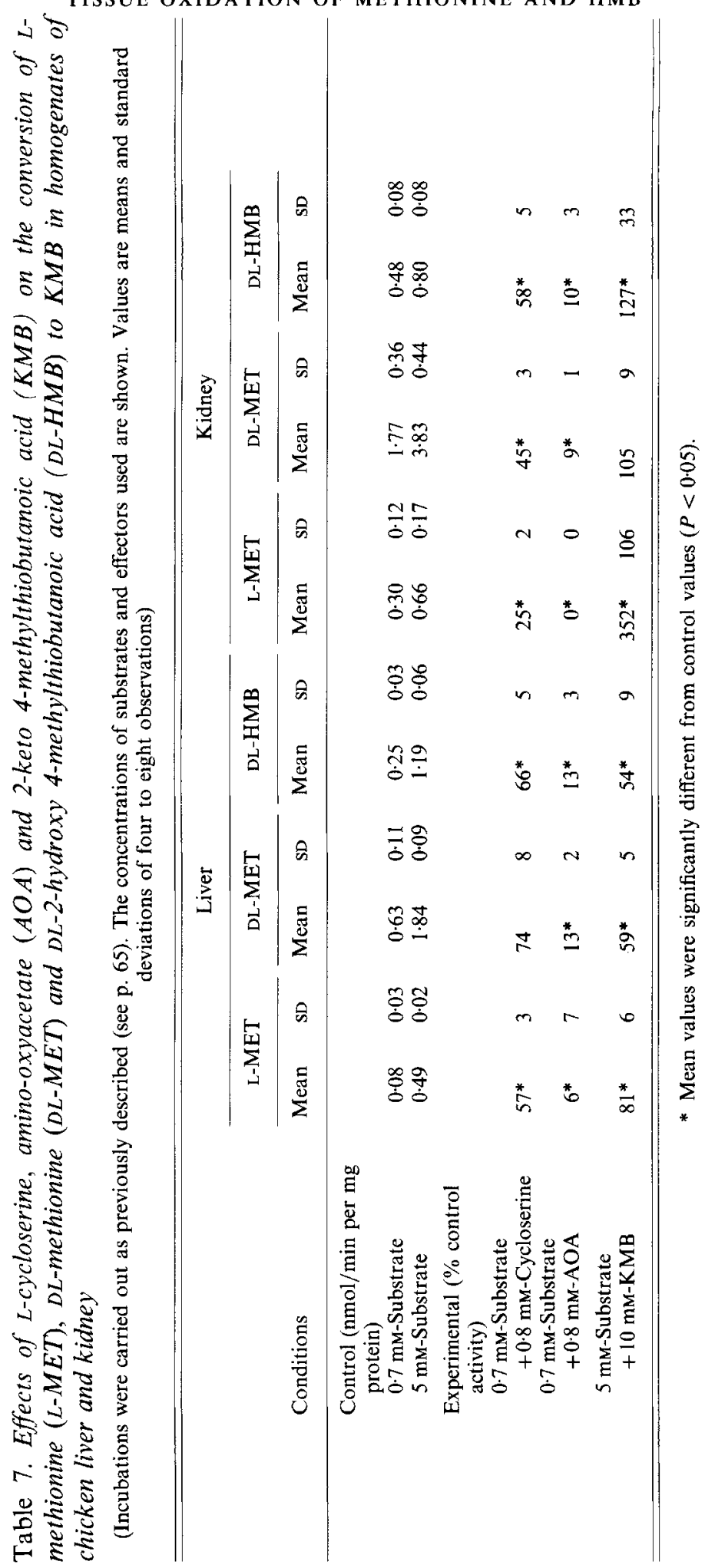




\section{Effects of transaminase and oxidase inhibitors on $L-M E T$ oxidation to KMB}

$\mathrm{L}$-Cycloserine and amino-oxyacetate are strong inhibitors of enzymes requiring pyridoxal phosphate in vitro, i.e. for cytosolic and mitochondrial alanine aminotransferases $(E C$ 2.6.1.2.; Hopper \& Segal, 1962) or aspartate aminotransferases (EC 2.6.1.1; Janski \& Cornell, 1981) from rat liver. L-Cycloserine $(0.8 \mathrm{mM})$ inhibited the production of KMB from L-MET in chicken liver and kidney homogenates by 43 and $75 \%$ respectively (Table 7). However, amino-oxyacetate was found to be a more potent inhibitor since the reaction was fully inhibited at $0.8 \mathrm{~mm}$ in both tissues. The two inhibitors also affected the oxidation of DL-MET and DL-HMB by liver and kidney homogenates. Once again, amino-oxyacetate was the most potent with an inhibition of about $90 \%$. The effect of $0.8 \mathrm{mM}$-L-cycloserine appeared to vary with the tissue, having no significant effect on DL-MET oxidation in liver but producing a marked inhibition of DL-MET oxidation in kidney and DL-HMB oxidation in both liver and kidney.

Glutamine transaminases ( $E C 2.6 .1 .15)$ have been shown to be highly active towards KMB in rat kidney and liver (Cooper \& Meister, 1972, 1974). Furthermore, the conversion of DL-HMB (calcium salt) to L-MET via KMB was reported to be stimulated by the addition of glutamine in the liver of the rat (Langer, 1965). As also shown in Table 7, the oxidation of L-MET and DL-HMB ( $5 \mathrm{mM}$ ), unlike that of DL-MET, by chicken kidney homogenates was significantly enhanced (3.5- and 1.3-fold respectively) when $10 \mathrm{mM}-\mathrm{KMB}$ were added to the incubation mixture. By contrast, adding KMB to the liver homogenate system significantly depressed the oxidation of DL-HMB (46\%), DL-MET (41\%) and L$\operatorname{MET}(19 \%)$.

\section{DISCUSSION}

Over the past few years, active research has been carried out to understand the efficiency with which HMB can replace MET in sulphur amino acid-deficient diets for growing chickens. This issue still remains a matter of controversy. The present studies are in agreement with previous findings (Gordon \& Sizer, 1955; Langer, 1965) on the tissue distribution of the metabolic conversion of DL-HMB into L-MET in the intact animal. Thus, at the low concentration of $0.7 \mathrm{~mm}$, the kidney contains the highest specific activity (per mg tissue protein) for oxidation of DL-HMB to KMB. However, because of its much greater weight, the liver may account for the major part in the total body oxidation of DL-HMB (0.7 mM) in chickens. At a considerably higher concentration (20 mM) the tissue distribution of the specific activities of oxidation was roughly unchanged, although the relative rates in muscle and intestinal mucosa were significantly increased. Assuming that the oxidation activity of breast muscle is representative of that of the body muscles, the muscular tissue would play a predominant role in whole-body oxidation of saturating concentrations of DL-HMB. However, it is most unlikely that such high concentrations would be found in vivo even in chickens fed on HMB-containing diets. On the other hand, although tissue and plasma HMB levels are unknown, we feel that the values of $0.7 \mathrm{~mm}$ provide reliable information on the enzymic oxidation of DL-HMB to KMB in the intact animal.

Several pieces of evidence suggest that the stereoisomers of HMB undergo separate oxidation to KMB in chicken liver. Substrates and inhibitors of L-HAOX and L-AAOX (glycolate, $\beta$-phenyl L-lactate and L-MET) and of D-HADH (D-lactate) partly inhibited oxidation of DL-HMB. When inhibitors of both types were included together in the incubation medium, DL-HMB oxidation was inhibited to a greater degree. Also the inhibition produced by D-HMB and L-HMB (calcium salt) together was greater than by either alone. The inhibitions of DL-HMB oxidation by D-HMB and D-lactate are similar 
and not increased by adding both together. This strongly suggests that these inhibitors affect the same enzyme, namely the D-HADH. The extent of this inhibition together with the effects of the inhibitor mixtures lead to the conclusion that each stereoisomer may account for about half the KMB formed from DL-HMB (at $0.7 \mathrm{mM}$ ). This would imply that the differences in nutritional efficiency of the stereoisomers (Baker \& Boebel, 1980) arise in the extrahepatic tissues. Recent studies using cultured pig-kidney fibroblasts (Schreiner \& Jones, 1987) would support this conclusion. The different degrees of inhibition of DL-HMB oxidation in chicken liver homogenates produced by $\beta$-phenyl L-lactate and glycolate suggest that there may be two enzymes involved in the oxidation of L-HMB, namely the LHAOX-A which has been identified in chicken liver and kidney peroxisomes (Scott $e t$ al. 1969 ) and an enzyme resembling the L-HAOX-B of pig and rat kidney (Robinson et al. 1962; Nakano \& Danowski, 1966; Cromartie \& Walsh, 1975). The inhibition of DL-HMB oxidation by L-MET would support this suggestion, although the lack of inhibition by $\mathrm{L}$-leucine and L-phenylalanine might cast some doubt. The inhibitory effects of $\mathrm{L}-\mathrm{HMB} \mathrm{Ca}^{2+}$ and $\beta$-phenyl L-lactate on L-MET oxidation and lack of effect of glycolate also suggest the existence of an L-AAOX active towards L-HMB in chicken liver.

The oxidation of DL-HMB by kidney and liver homogenates was unaltered when changing the incubation $\mathrm{pH}$ from 7.5 to $8 \cdot 6$. This presumably results from the concomitant increase and decrease of oxidation activities of L-HMB and D-HMB respectively, as previously reported by Dibner \& Knight (1984) in experiments with mitochondrial and peroxisomal fractions. FMN and FAD, which are the prosthetic groups of all the L-HAOX enzymes and of D-HADH respectively, did not stimulate the oxidation of DL-HMB in chicken tissue homogenates. This suggests that neither flavin cofactor was rate-limiting in our studies.

Direct measurements of oxidation activities clearly indicate that whatever the concentration used, DL-MET was much more rapidly converted to KMB than DL-HMB and L-MET in whole tissues except breast muscle. Most of the KMB produced from DLMET in homogenates of intestinal mucosa, kidney, liver and muscle (at $20 \mathrm{~mm}$ only for the latter) would therefore result from the enzymic oxidation of the D-isomer. The renal tissue appeared to be by far the most active towards D-MET. This agrees with previous reports on the organ distribution of D-AAOX in many other species (Masters \& Holmes, 1977). In addition, we have shown the presence of a D-AAOX activity in chicken intestinal mucosa, thus confirming observations that microperoxisomal particles containing D-AAOX are present in guinea-pig enterocytes (Novikoff \& Novikoff, 1972; Peters, 1972). The existence of oxidase activity in goldfish (Carassius auratus) intestinal peroxisomes (Connock, 1973) argues for the wide distribution of D-AAOX in the gut of many species.

Our finding that increasing the $\mathrm{pH}$ from 7.5 to 8.6 enhanced the oxidation of DL-MET by liver and kidney homogenates is consistent with previous reports on $\mathrm{pH}$ curves of purified pig kidney D-AAOX for D-MET (Dixon \& Kleppe, 1965a,b). Although the enzyme binds the FAD coenzyme (Masters \& Holmes, 1977), no acceleration of KMB formation resulted from the addition of large amounts of the cofactor to liver and kidney homogenates, as also observed for DL-HMB oxidation. Inhibitors of DL-MET oxidation by chicken liver homogenates (Table 5) were highly comparable with those of pure D-AAOX of pig kidney. Moreover, both stereoisomers of HMB, as well as L-MET, inhibit the reaction; this agrees with the suggestion that it is the side chain of the amino or the hydroxy acid which combines with the enzyme's active centre (Dixon \& Kleppe, 1965a).

The findings that D- and L-HMB inhibited, and D-MET stimulated, L-MET oxidation by chicken liver homogenates (Table 5) imply that the structural analogues may interfere with the metabolism of each other. This possibility merits further investigation, particularly when animals are fed on compound rations which contain L-MET together with D-MET 
or DL-HMB. The mechanisms by which D-lactate and D-HMB decreased L-MET oxidation remain unknown to us. The increase in L-MET oxidation brought about by $10 \mathrm{mM}-\mathrm{D}-\mathrm{MET}$ cannot be due to the effect of an increased amount of KMB resulting from the oxidation of the D-isomer since $10 \mathrm{mM}-\mathrm{KMB}$ exerted significant inhibition on the accumulation of $\left[{ }^{14} \mathrm{C}\right] \mathrm{KMB}$ from $\mathrm{L}-\left[1-{ }^{14} \mathrm{C}\right] \mathrm{MET}$ in liver homogenates. In kidney homogenates, a high concentration of KMB stimulated the oxidation of L-MET 3-5-fold. This is consistent with the involvement of transaminases in the oxidation of L-MET to KMB and with the possibility that the keto acid can serve as a transamination co-substrate for rat kidney glutamine transaminase K (Cooper \& Meister, 1974) and for L-MET transamination in rat kidney homogenates (Mitchell \& Benevenga, 1978). However, our results clearly indicate that rat and chicken appear to differ regarding their hepatic ability to convert L-MET to KMB. Mitchell \& Benevenga (1978) observed a stimulation of L-MET transamination by $\mathrm{KMB}$ in the liver of rats. However, their findings are not consistent with reports that, at concentrations higher than $5 \mathrm{~mm}, \mathrm{KMB}$ irreversibly inhibited glutamine transaminase purified from rat liver (Cooper \& Meister, 1972). Other experiments with transaminase inhibitors did not allow us to establish a link between L-MET oxidation and transamination since other activities were strikingly affected. The extent of the decrease by L-cycloserine was dependent on the tissue, suggesting that the liver and kidney enzymes concerned with L-MET oxidation may have different characteristics.

Extrapolation from breast muscle to the whole muscle mass led us to consider that the muscular tissue would contribute predominantly to L-MET oxidation in the intact chicken. This result is in general agreement with the findings of Mitchell \& Benevenga (1978) using rats. We also deduced that muscle tissue accounts for a significant amount of whole-body D-MET oxidation. However, the relative contribution of the liver and kidney to D-MET oxidation would be higher. As already mentioned, the actual rates of L-MET, D-MET and DL-HMB oxidation in vivo and the tissue distribution of each process will depend not only on enzyme activity but also on the amount of substrate reaching the site of enzyme activity. This appears to be influenced by many factors such as MET, HMB or protein content of chicken rations (Saunderson, 1987) and therefore merits further investigation.

\section{REFERENCES}

Baker, D. H. \& Boebel, K. P. (1980). Utilization of the D- and L-isomers of methionine and methionine hydroxy analogue as determined by chick bioassay. Journal of Nutrition 110, 959-964.

Benevenga, N. J., Radcliffe, B. C. \& Egan, A. R. (1983). Tissue metabolism of methionine in sheep. Australian Journal of Biological Science 36, 475-485.

Brachet, P., Dupuis, L. \& Puigserver, A. (1986). Comparative intestinal absorption and tissue metabolism of methionine and $\alpha$-hydroxy $\gamma$-methylthiobutyric acid by broiler chicks. Proceedings of the 7 th European Poultry Conference, vol. 1, pp. 307-311 [M. Larbier, editor]. Tours, France: World's Poultry Science Association.

Brachet, P. \& Puigserver, A. (1987). Transport of methionine hydroxy analog across the brush border membrane of rat jejunum. Journal of Nutrition 117, 1241--1246.

Cammack, R. (1969). Assay, purification and properties of mammalian D-2-hydroxy acid dehydrogenase Biochemical Journal 115, 55-64.

Cleland, W. W. (1979). Statistical analysis of enzyme kinetic data. Methods in Enzymology 63A, 103-138.

Connock, M. J. (1973). Intestinal peroxisomes in goldfish (Carassius auratus). Comparative Biochemistry and Physiology 45A, 945-951.

Cooper, A. J. L. \& Meister, A. (1972). Isolation and properties of highly purified glutamine transaminase. Biochemistry 11, 661-671.

Cooper, A. J. L. \& Meister, A. (1974). Isolation and properties of a new glutamine transaminase from rat kidney. Journal of Biological Chemistry 249, 2554-2561.

Cromartie, T. H. \& Walsh, C. T. (1975). Rat kidney L- $\alpha$-hydroxy acid oxidase. Isolation of enzyme with one flavine coenzyme per two subunits. Biochemistry 14, 2588-2596.

Dibner, J. J. (1983). Utilization of supplemental methionine sources by primary cultures of chick hepatocytes. Journal of Nutrition 113, 2116-2123. 
Dibner, J. J. \& Knight, C. D. (1984). Conversion of 2-hydroxy-4 (methylthio) butanoic acid to L-methionine in the chick: a stereospecific pathway. Journal of Nutrition 114, 1716-1723.

Dixon, M. \& Kleppe, K. (1965a). D-amino acid oxidase. II. Specificity, competitive inhibition and reaction sequence. Biochimica et Biophysica Acta 96, 368-382.

Dixon, M. \& Kleppe, K. (1965b). D-amino acid oxidase. III. Effect of pH. Biochimica et Biophysica Acta 96, 383-389.

Featherston, W. R. \& Horn, G. W. (1974). Studies on the utilization of the $\alpha$-hydroxy acid of methionine by chicks fed crystalline amino acids (diets). Poultry Science 53, 680-686.

Gordon, R. S. \& Sizer, I. W. (1955). The biological equivalence of methionine hydroxy analogue. Poultry Science 34, 1198.

Gordon, R. S. \& Sizer, I. W. (1965). Conversion of methionine hydroxy analogue to methionine in the chick. Poultry Science 44, 673-678.

Graser, T. A., Godel, H. G., Albers, S., Földi, P. \& Fürst, P. (1985). An ultrarapid and sensitive high-performance liquid chromatographic method for determination of tissue and plasma free amino acids. Analytical Biochemistry 151, 142-152.

Hartree, E. F. (1972). Determination of protein. A modification of the Lowry method that gives a linear photometric response. Analytical Biochemistry 48, 422-427.

Hauschildt, S. \& Brand, K. (1980). Effects of branched-chain $\alpha$-keto acids on enzymes involved in branched-chain $\alpha$-keto acid metabolism in rat tissues. Journal of Nutrition 110, 1709-1716.

Hopper, S. \& Segal, H. L. (1962). Purification and properties of liver glutamic-alanine transaminase from normal and corticoid treated rats. Journal of Biological Chemistry 237, 3189-3195.

Janski, A. M. \& Cornell, N. W. (1981). Inhibition by cycloserine of mitochondrial and cytosolic aspartate aminotransferase in isolated rat hepatocytes. Biochemical Journal 194, 1027-1030.

Jones, S. M. A. \& Yeaman, S. J. (1986). Oxidative decarboxylation of 4-methylthio-2-oxobutyrate by branchedchain 2-oxo acid dehydrogenase complex. Biochemical Journal 237, 621-623.

Langer, B. W. (1965). The biochemical conversion of 2-hydroxy-4-methylthiobutyric acid into methionine by the rat in vitro. Biochemical Journal 95, 683-687.

Lerner, J., Yankelowitz, S. \& Taylor, M. W. (1969). The intestinal absorption of methionine in chickens provided with permanent Thiry-Vella fistulas. Experientia 25, 689-691.

Masters, C. \& Holmes, R. (1977). Peroxisomes: new aspects of cell physiology and biochemistry. Physiological Reviews 57, 816-882.

Mitchell, A. D. \& Benevenga, N. J. (1978). The role of transamination in methionine oxidation in the rat. Journal of Nutrition 108, 67-78.

Muramatsu, T., Yokota, H., Okumura, J. \& Tasaki, I. (1984). Biological efficacy of liquid methionine and methionine hydroxy analogue free acids in chicks. Poultry Science 63, 1453-1456.

Nakano, M. \& Danowski, T.S. (1966). Crystalline mammalian L-amino acid oxidase from rat kidney mitochondria. Journal of Biological Chemistry 241, 2075-2083.

Nakano, M., Ushijima, Y., Saga, M., Tsutsumi, Y. \& Asami, H. (1968). Aliphatic L- $\alpha$-hydroxy acid oxidases from rat livers. Purification and properties. Biochimica et Biophysica Acta 167, 9-22.

Novikoff, P. M. \& Novikoff, A. B. (1972). Peroxisomes in absorptive cells of mammalian small intestine. Journal of Cell Biology 53, 532-560.

Odessey, R. \& Goldberg, A. L. (1979). Leucine degradation in cell-free extracts of skeletal muscle. Biochemical Journal 178, 475-484.

Peters, T. J. (1972). Cited by De Duve, C. (1973). Biochemical studies on the occurrence, biogenesis and life history of mammalian peroxisomes. Journal of Histochemistry and Cytochemistry 21, 941-948.

Robinson, J. C., Keay, L., Molinari, R. \& Sizer, I. W. (1962). L- $x$-hydroxy acid oxidases of hog renal cortex. Journal of Biological Chemistry 237, 2001-2010.

Saunderson, C. L. (1985). Comparative metabolism of L-methionine, D,L-methionine and D,L-2-hydroxy-4methylthiobutanoic acid by broiler chicks. British Journal of Nutrition 54, 621-633.

Saunderson, C. L. (1987). Effect of fasting and of methionine deficiency on L-methionine, D,L-methionine and D,L2-hydroxy-4-methylthiobutanoic acid metabolism in broiler chicks. British Journal of Nutrition 57, 429437.

Schreiner, C. L. \& Jones, E. E. (1987). Metabolism of methionine and methionine hydroxy analogue by porcine kidney fibroblasts. Journal of Nutrition 117, 1541-1549.

Scott, P. J., Visentin, L. P. \& Allen, J. M. (1969). The enzymatic characteristics of peroxisomes of amphibian and avian liver and kidney. Annals of the New York Academy of Sciences 168, 244-264.

Tubbs, P. K. \& Greville, G. D. (1961). The oxidation of D- $\alpha$-hydroxy acids in animal tissues. Biochemical Journal 81, 104-114. 